\title{
Study of Some Polypropylene Nanocomposite Properties
}

\author{
Abou El-Fettoh A. Abd El-Hakim ${ }^{*}$, Abdallah A. El-Sawey ${ }^{2}$, A.M. Motawie ${ }^{3}$, \\ Alaa I. Eid ${ }^{4}$, N.S. Mahruos ${ }^{5}$ \\ ${ }^{1}$ Polymer Chemistry and Technology, National Research Center NRC, El dokki. \\ ${ }^{2}$ Organic Chemistry, Faculty of Science, Benha University, Egypt. \\ ${ }^{3}$ Petrochemical Department, Egyptian Petroleum ResearchInstitute EPRI, Nasr City, \\ Cairo.Egypt. \\ ${ }^{4}$ Metallurgical\& Development Institute. \\ ${ }^{5}$ El Taqwa Pure Company.
}

\begin{abstract}
THE PREPARATION of both polymer composites and nanocomposites by melt compounding of polypropylene (PP) with micro $\mathrm{CaCO}_{3}$ content $1,3,5,7,10,15$ and 20 wt. $\%$ and nano $\mathrm{CaCO}_{3}$ content $1,3,5,7$ and $10 \mathrm{wt} . \%$ using fatty carboxylic acid as compatibilizer has been done. The presence of agglomerations of $\mathrm{CaCO}_{3}$ with increasing the content in the composites must be taken into account. The prepared composites were characterized by using Fourier transform infrared spectroscopy (FTIR), X-Ray Diffraction (XRD), Transmission Electron Microscopy (TEM). Mechanical, Electrical, Thermal, and Physical properties of PP composites and nanocomposites was obtained and compared to virgin PP.
\end{abstract}

Keywords: Polypropylene, Calcium carbonate, Nanocomposite, Physical, Mechanical, Electrical, Thermal properties.

\section{Introduction}

Polypropylene (PP) has various advantages such as easy conversion, good (hardness, environmental stress, cracking resistance, fatigue resistance) as well as resistance to temperatures when not subjected to mechanical stress, higher stiffness at lower density and the most distinctive advantage is the addition of low-cost materials such as calcium carbonate, talc, clay and fibre... etc. These materials with low cost play very important role in polypropylene properties.

$\mathrm{CaCO}_{3}$ is widely used as filler with PP due to the low cost, abundance on nature and could improve mechanical, physical properties and increase the thermal stability. But, there's a main problem of using inorganic minerals with polyolefin is the poor interfacial bonding between them due to hydrophilic nature of the inorganic minerals inherently incompatible with hydrophobic polyolefins $[1,2]$. To overcome this problem the inorganic minerals usually treated with Carboxylic acids (fatty acids) which used as a coupling agent (Compatibilizer). In this study the mechanical and Thermal properties of PP composites and nanocomposites were investigated. The physical and electrical properties were determined and compared to virgin PP.

\section{Experimental}

Materials

PP (Hostalen PP H5416, LYONDELL BASELL) provided by Basell company, its density was $0.897 \mathrm{~g} / \mathrm{cm}^{3}$. Melt flow index was 0.3 $\mathrm{g} / 10 \mathrm{~min}\left(2.16 \mathrm{~kg}\right.$ at $\left.230{ }^{\circ} \mathrm{C}\right), 0.5 \mathrm{~g} / 10 \mathrm{~min}(5 \mathrm{~kg}$ at $\left.190{ }^{\circ} \mathrm{C}\right)$ and $1.3 \mathrm{~g} / 10 \mathrm{~min}\left(5 \mathrm{~kg}\right.$ at $\left.230^{\circ} \mathrm{C}\right)$ and the melting temperatures were $147^{\circ} \mathrm{C}$. Calcium Carbonate (micron size) filler is purchased from the ASCOM 20T is produced from highly white limestone and milled to a medium particle size with $\mathrm{CaCO}_{3}$ content $99.6 \%$, main particle size was 24 - 26 microns, and brightness (95.8\%) treated with Stearic Acid 7 - 8 KG/Ton. Calcium Carbonate (nano size) filler is purchased from Solvay, France. (Socal 312, Solvay, France). Ultrafine, white and odorless coated precipitated calcium carbonate with $\mathrm{CaCO}_{3}$ content $99.6 \%$ and main particle diameter of $70 \mathrm{~nm}$, specific surface area $\left(17 \mathrm{~m}^{2} / \mathrm{g}\right)$ and brightness $(97 \%)$ used as filler phase. PP-g-MAH compatibilizer (Priex 20097, Solvay, France) with maleic anhydride content of $0.05 \mathrm{wt} \%$.

Preparation of PP composites and nanocomposites All samples were prepared in a Barbender Carl Wihelm (C.W Barbender instruments inc) for plastic-corder inter faceco-rotating twin- 
screw extruder $(D=20 \mathrm{~mm}, \mathrm{~L}=440 \mathrm{~mm}$ and $\mathrm{L} / \mathrm{D}$ 1/22) Barrel and Screw NO 18252 OB2. Internal mixer at $200-210{ }^{\circ} \mathrm{C}$. Other conditions where 70 r.p.m and $10 \mathrm{~min}$ homogenization time. Then, the extruder put into the roll mill for extremely mixing and good uniform distribution then, comprised by the press that for test preparing sample for hardness, melt flow rate, tensile, electrical and thermal analysis. The weight content of Calcium Carbonate (micron size) were 1, 3, 5, 7, 10, 15 and $20 \%$ wt and Calcium Carbonate (nano size) were $1,3,5,7$ and $10 \%$ wt.

Characterization of the prepared composites. FTIR spectroscopy

The term Fourier transform (FT) refers to a modern development in the method in 66 which the data are collected and converted from an interference pattern to an infrared absorption spectrum that is like a molecular "fingerprint"[3].

The analysis was carried out by using FTIR 6300. Fourier Transform Infrared spectrometer in the wave number range $\left(400-4000 \mathrm{~cm}^{-1}\right)$.

\section{Morphological Analysis}

$X$-ray Diffraction (XRD)

The samples of the wide-angle X-ray diffraction (WAXD) examinations were cut from the mechanical testing specimens. The WAXD experiments were conducted with PW 710 BASED /PC X-ray diffractometer. $\mathrm{Cu} \mathrm{K} \alpha(\lambda$ $=1.54 \AA$ ) radiation, generated at a voltage of 40 $\mathrm{kv}$ and current of $55 \mathrm{~mA}$ was used as the X-Ray source. The diffraction angle $2 \theta$ was scanned from $3^{\circ}$ to $45^{\circ}$ at a scanning rate of $1 \% \mathrm{~min}$ and a step size of $0.02^{\circ}$. The molded specimens were used as the X-ray diffraction samples.

Transmission Electron Microscopy (TEM) Analysis

TEM is a very effective technique for the study of polymer morphology. Both 84 XRD and TEM are essential tools for evaluating the nanocomposite structure. However, TEM gives qualitative information on the sample such as internal structure, distribution of the various phases, whereas peaks in XRD allow quantification of changes in layer spacing.

The photographs were taken by using( Model: JEM-1230-Made in Japan-JEOL Co.-energy $120 \mathrm{KV}$ on steps-Line Resolution: $0.2 \mathrm{~nm}-\mathrm{Max}$. Magn.:600Kx).

\section{Mechanical Tests}

Tensile Test

Tensile tests were performed on five samples for each composition according to the standards of EN-ISO 527-1 [4] and EN-ISO 527-2 [5] (international standards and organization) by using standardized TestometricM500-50ATUniversal testing machine.

Impact Test

The impact strength test shall be carried out according to DIN EN ISO 179-1 (Plastics Determination of Charpy Impact Strength) with pendulum Ceast ResilI mpactoron 10 test pieces using a $15 \mathrm{~J}$ pendulum impact testing machine with the blow being applied to the external sample surface or the machined side at velocity $=3.8 \mathrm{~m} / \mathrm{sec}$. The test shall be carried out at $(23$ $\pm 2^{\circ} \mathrm{C}$ ) by using SANS ZBC- 50A manufacture by SHENZHEN SANS TESTING MACHINE CO., LTD.

\section{Hardness}

the test was carried out by using the Shore "D" Durometer with scales from 0 to 100 .

\section{Electrical properties}

Electrical and dielectric measurements were carried out at room temperature using PM 6304 programmable automatic RCL (Philips) meter, over frequency range from $100 \mathrm{HZ}$ to $100 \mathrm{KHZ}$.

\section{Thermal Analysis}

Thermal Analysis test (Differential Scanning Calorimetry (DSC) and Thermogravimetric Analysis (TGA)) were carried out at $23{ }^{\circ} \mathrm{C}$ (beginning of test ) to $500^{\circ} \mathrm{C}$ By heating rate $10^{\circ} \mathrm{C}$ per minute using Universal V4.7A TA Instruments (SDT Q600 V20.9 Build 20).

\section{Physical properties \\ Density}

Density test was carried out at $23{ }^{\circ} \mathrm{C}$, Using Sartorius mecatronics instrument within convex filter blow this because of the density of pp, pp/ $\mathrm{CaCO}_{3}$ composite and nanocomposite $<\mathrm{H}_{2} \mathrm{O}$ density.

\section{Water Absorption Test}

The test was carried out according to ASTM D $570[6]$ in temperature $23{ }^{\circ} \mathrm{C}$ and humidity $50 \%$.

\section{Flow Characteristics}

Melt Flow Index (MFI) Test

The melt mass-flow rate (MFR) and the melt volume-flow rate (MVR) were determined according to iso 1133-1:2011(E) [7] by using IPT 1267-2036308212 Melt flow rate instrument.

\section{Heat reversion}

The longitudinal reversion was determined 
according to DIN EN ISO 2505[8] using method $\mathrm{B}$, which depend upon determination longitudinal reversion on air. The test was carried out using thermo electron corporation manufacture by heraeus.

\section{Vicat Softening Temperature and Heat Deflection} Temperature

Vicat Softening Temperature test was carried out according to ASTM D-2515-00 and Heat Deflection Temperature test was carried out according to ASTM D648 [9] or ISO 75 using (VST)/B/50/K/h(50N)).

\section{Results}

Physicochemical characterization

\section{FTIR spectroscopy}

There are new peaks in Fig. 1 appears nearly at 1735,2018 and $2125 \mathrm{~cm}^{-1}$ represented $\mathrm{CH}_{3}$ groups of PP. the peak at $2912 \mathrm{~cm}^{-1}$ represented $\mathrm{CH}_{3}$ groups. Increasing loads of $\mathrm{CaCO}_{3}$ in $\mathrm{PP}$ matrix didn't affect in the intensity and position of the peaks. This indicates that there is no interaction between $\mathrm{PP}$ and $\mathrm{CaCO}_{3}$ particles. The $\mathrm{CaCO}_{3}$ particles are existed inside the PP particles by physical interaction[3].

\section{Morphological Analysis}

$X$-Ray Diffraction (XRD) Analysis

For virgin PP presents peaks characteristics of $\alpha$ phase in $2 \theta$ values of $14.365,16.905,18.86$, 21.375 and $22.295^{\circ}$ corresponding to (110), (040), (130), (111) and (131) lattice planes of the most common $\alpha$-monoclinic crystal[10,11]. For both $\mathrm{PP} / \mathrm{CaCO}_{3}$ composite and nanocomposite represented in Fig. 2, there are new peaks at $2 \theta$ of around $16.0^{\circ}$ was observed. It is assigned to (300) lattice plane of $\beta$-crystal, indicating the existence of $\beta$-crystal in PP composites and nanocomposites [13], due to presence of $\mathrm{CaCO}_{3}$.

Transmission Electron Microscopy (TEM) Analysis

For $\mathrm{PP} / \mathrm{CaCO}_{3}$ composite (Fig.3), it was showed that there's a good dispersion of $\mathrm{CaCO}_{3}$ in PP matrix within low contents 3 and $7 \%$, but for higher contents $15 \% \mathrm{CaCO}_{3}$ begin to agglomerate.

For $\mathrm{PP} / \mathrm{CaCO}_{3}$ nanocomposite (Fig.4), due to strong tendency of nanoparticles to agglomerate than micro, the percent of nano $\mathrm{CaCO}_{3}$ add to $\mathrm{PP}$ forming the nanocomposite is less than that of the composite. It was showed that there's a good dispersion of $\mathrm{CaCO}_{3}$ in PP matrix within low contents 3 and $5 \%$, for high contents $7 \% \mathrm{CaCO}_{3}$ begin to agglomerate.

$\mathrm{PP} / \mathrm{CaCO}_{3}$ composite

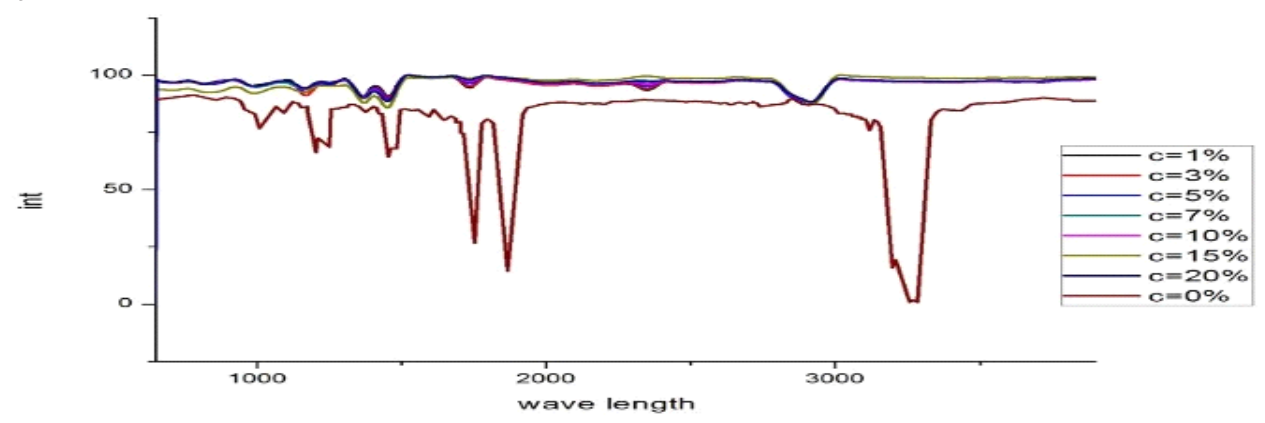

$\mathrm{PP} / \mathrm{CaCO}_{3}$ nanocomposite

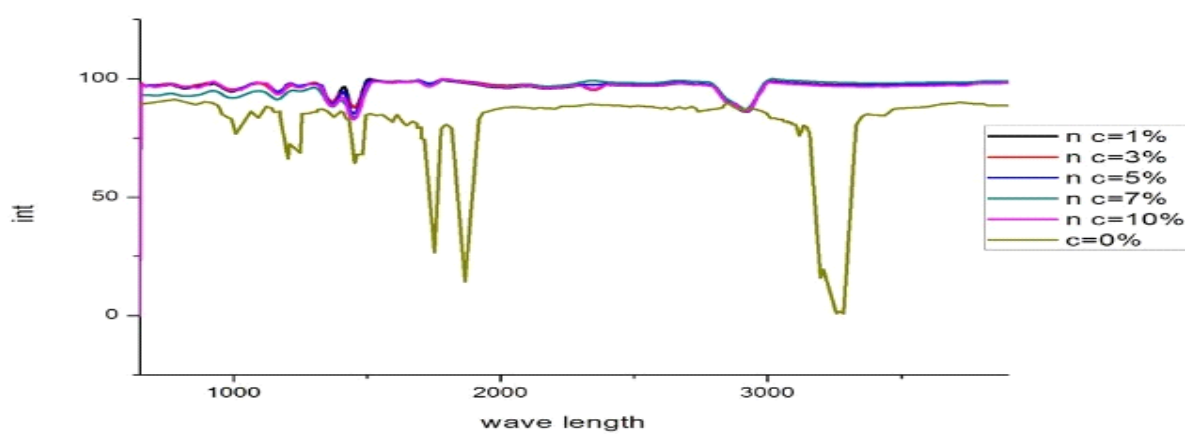

Fig. 1. IR spectrum for $\mathrm{PP} / \mathrm{CaCO}_{3}$ composite and $\mathrm{PP} / \mathrm{CaCO}_{3}$ nanocomposite.

Egypt. J. Chem. 61, No.5 (2018) 
$\mathrm{PP} / \mathrm{CaCO}_{3}$ composite

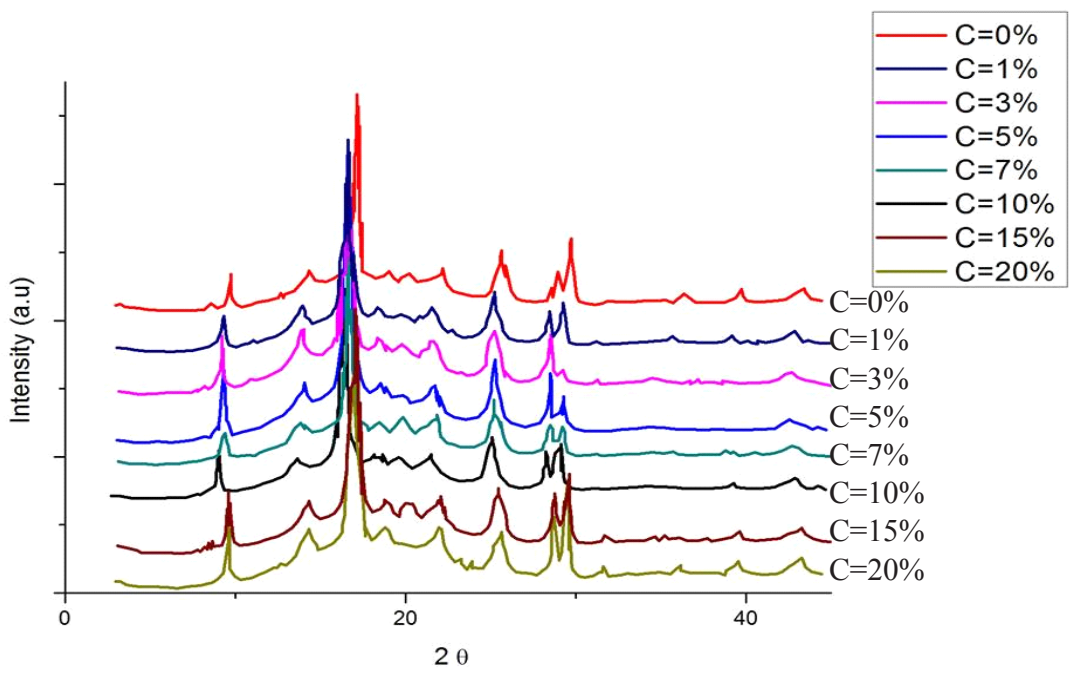

PP/CaCO3 nanocomposite

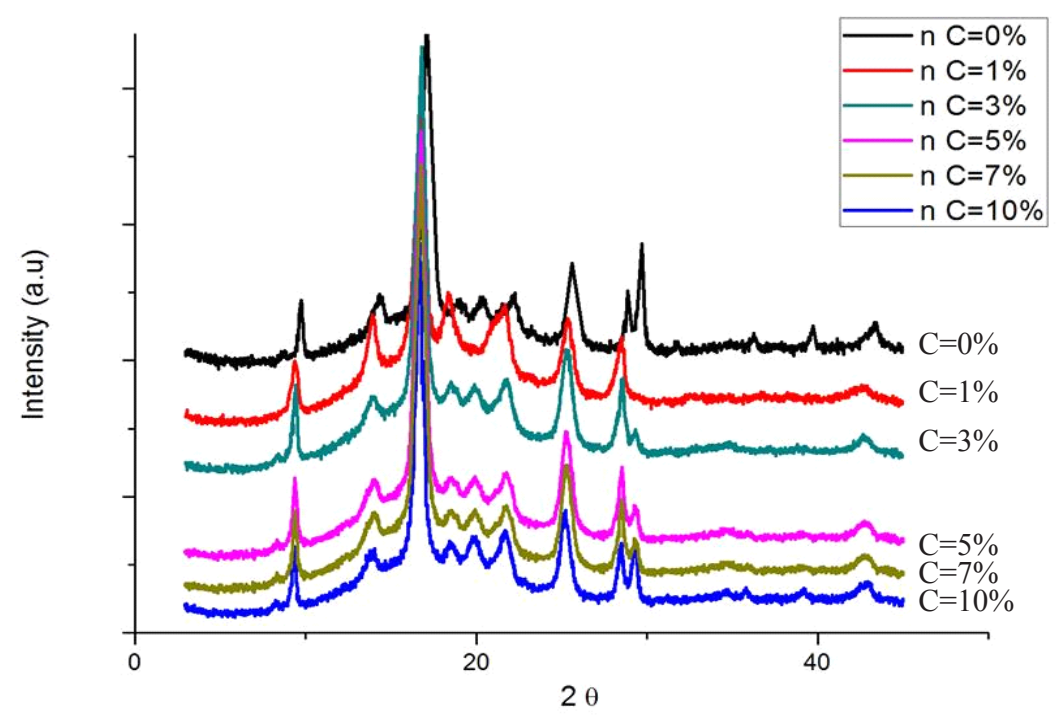

Fig. 2. $\mathrm{XRD}$ for $\mathrm{PP} / \mathrm{CaCO}_{3}$ composite and $\mathrm{PP} / \mathrm{CaCO}_{3}$ nanocomposite. 

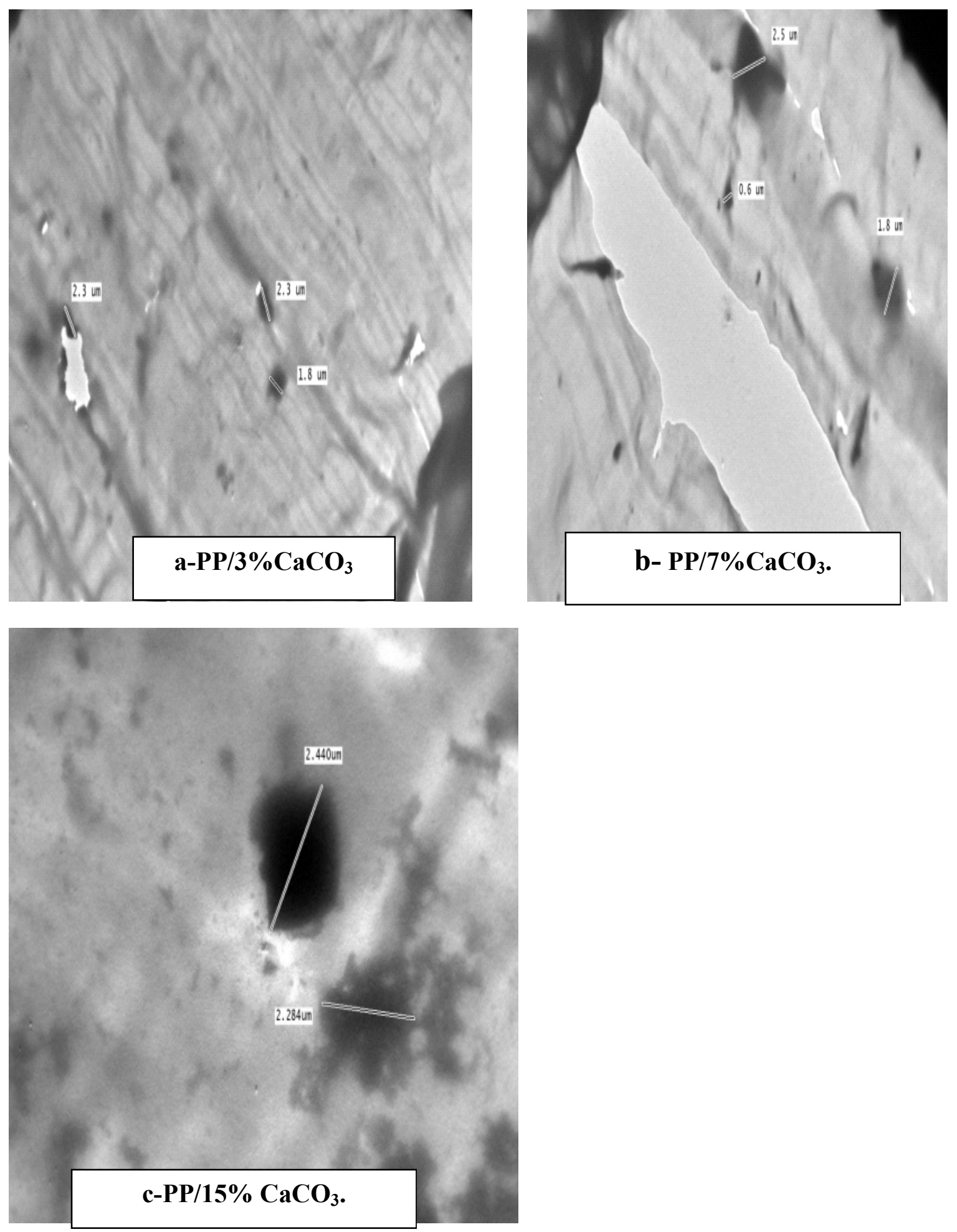

Fig. 3. TEM micrographs for $\mathrm{PP} / \mathrm{CaCO}_{3}$ composite.

Egypt. J. Chem. 61, No.5 (2018) 

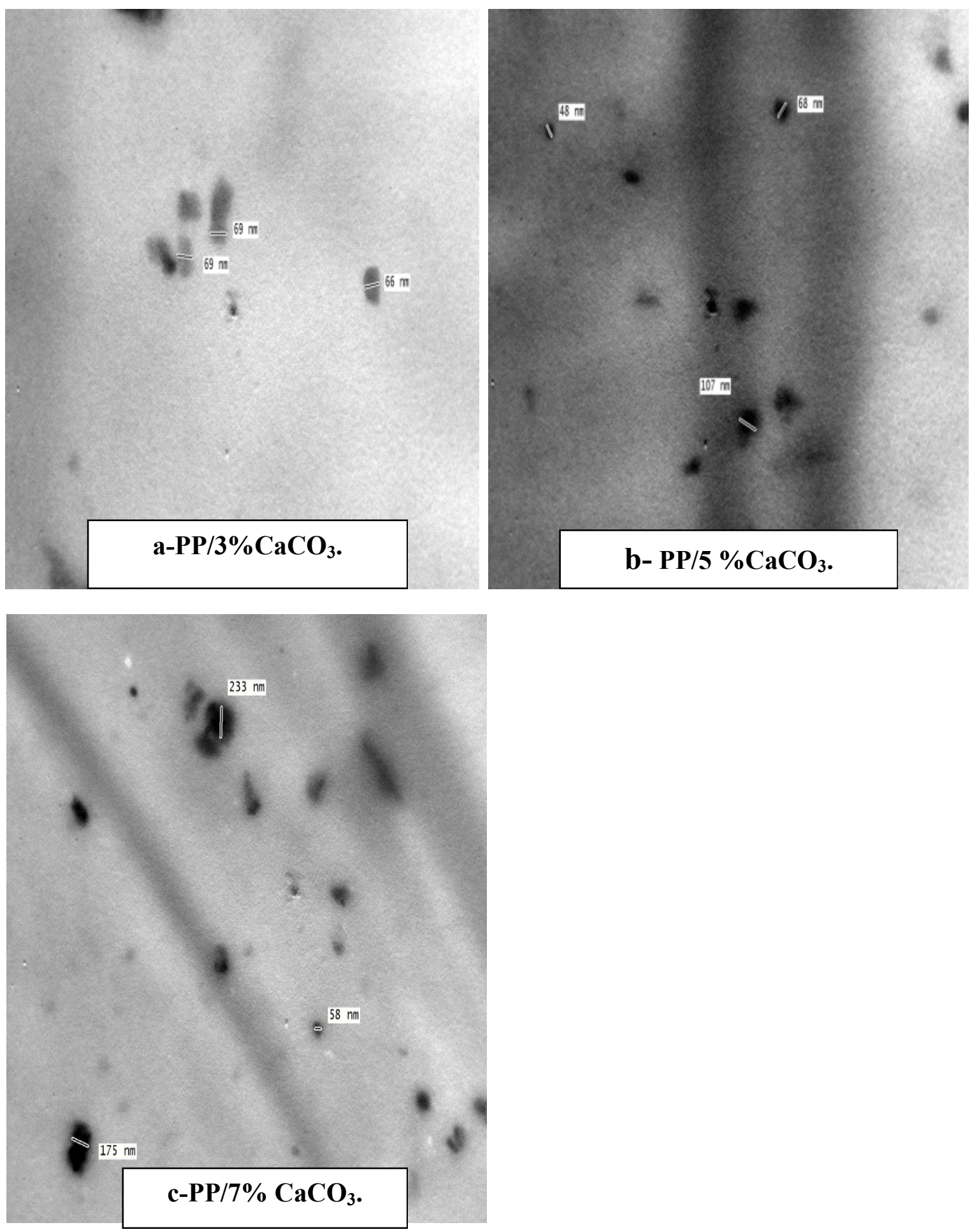

Fig. 4. TEM micrographs for $\mathrm{PP} / \mathrm{CaCO}_{3}$ nanocomposite. 


\section{Mechanical properties study}

TABLE 1. Impact results for $\mathrm{PP} / \mathrm{CaCO}_{3}$ composite and $\mathrm{PP} / \mathrm{CaCO}_{3}$ nanocomposite. a-PP/CaCO 3 composite.

b-PP/CaCO ${ }_{3}$ nanocomposite.

\begin{tabular}{|c|c|c|c|c|c|c|c|c|c|}
\hline $\begin{array}{c}\mathrm{CaCO}_{3} \% \\
\text { contents }\end{array}$ & $\begin{array}{c}\text { Total } \\
\text { test } \\
\text { sample }\end{array}$ & $\begin{array}{c}\text { pass } \\
\text { sample }\end{array}$ & $\begin{array}{l}\text { failure } \\
\text { sample }\end{array}$ & Results & $\begin{array}{c}\mathrm{CaCO}_{3} \% \\
\text { contents }\end{array}$ & $\begin{array}{c}\text { Total } \\
\text { test } \\
\text { sample }\end{array}$ & $\begin{array}{c}\text { pass } \\
\text { sample }\end{array}$ & $\begin{array}{l}\text { failure } \\
\text { sample }\end{array}$ & Results \\
\hline $0 \%$ & 10 & 10 & 0 & pass & $0 \%$ & 10 & 10 & 0 & pass \\
\hline $1 \%$ & 10 & 10 & 0 & pass & $1 \%$ & 10 & 10 & 0 & pass \\
\hline $3 \%$ & 10 & 10 & 0 & pass & $3 \%$ & 10 & 10 & 0 & pass \\
\hline $5 \%$ & 10 & 10 & 0 & pass & $5 \%$ & 10 & 10 & 0 & pass \\
\hline $7 \%$ & 10 & 10 & 0 & pass & $7 \%$ & 10 & 10 & 0 & pass \\
\hline $10 \%$ & 10 & 10 & 0 & pass & $10 \%$ & 10 & 10 & 0 & pass \\
\hline $15 \%$ & 30 & 28 & 2 & pass & & & & & \\
\hline $20 \%$ & 30 & 26 & 4 & fail & & & & & \\
\hline
\end{tabular}

TABLE2. Hardness results for $\mathrm{PP} / \mathrm{CaCO}_{3}$ composite and $\mathrm{PP} / \mathrm{CaCO}_{3}$ nanocomposite. a-PP/CaCO 3 composite. b-PP/CaCO nanocomposite.

\begin{tabular}{ccccc}
\hline $\mathrm{CaCO}_{3} \%$ contents & Hardness(shore $\mathrm{D})$ & $\mathrm{CaCO}_{3} \%$ contents & Hardness(shore D) \\
\cline { 1 - 2 } $1 \%$ & 65 & 66 & $0 \%$ & 65 \\
$3 \%$ & 67 & & $3 \%$ & 66 \\
$5 \%$ & 67 & $5 \%$ & 67 \\
$7 \%$ & 66 & & $7 \%$ & 68 \\
$10 \%$ & 68 & $10 \%$ & 69 \\
$15 \%$ & 69 & & 70 \\
$20 \%$ & 70 & & \\
\hline
\end{tabular}

At these percent which give the best mechanical properties and flow rate of the composite, within increase of $\mathrm{CaCO}_{3}$ addition the mechanical properties and flow rate of the prepared composite decreased given lower results for the composite due to $\mathrm{CaCO}_{3}$ agglomeration.

Agglomeration and nano $\mathrm{CaCO}_{3}$ diameters play important roles in properties level of samples. The agglomeration extent increases by addition of nano $\mathrm{CaCO}_{3}$ content and reduction of nano $\mathrm{CaCO}_{3}$ size. Moreover, the agglomeration decreases the effectiveness of nano $\mathrm{CaCO}_{3}$ in polypropylene matrix, which finally results in the poor properties of samples [12].

\section{Tensile Test}

Increasing the amount of $\mathrm{CaCO}_{3}$ in $\mathrm{PP}$ composite from $1 \%$ up to $20 \%$, enough to decrease the tensile strength from 28.803 to $21.544 \mathrm{Mpa}$ and the elongation increase from $123.47 \%$ to about $200 \%$, recording it's maximum value at $15 \%(229 \%)$ referring to collapse in the mechanical properties, where the young's modulus changed from 830.296 up to $805.225 \mathrm{~mm}$ recording it's maximum value at $5 \%$ (1022.267 $\mathrm{mm})$. For $\mathrm{PP} / \mathrm{CaCO}_{3}$ nanocomposite, increasing the amount of nano $\mathrm{CaCO}_{3}$ in PP from $1 \%$ up to $10 \%$, enough to decreases the tensile strength from 28.803 to $25.404 \mathrm{Mpa}$ and the elongation increase from $123.47 \%$ to about $235 \%$, recording it's maximum value at $7 \%(246 \%)$ referring to collapse in the mechanical properties, where the young's modulus changed from 830.296 up to $343.443 \mathrm{~mm}$ recording it's maximum value at $7 \%$ (888.683mm) (Fig. 5).

In general at the appropriate manufacture conditions the addition of $\mathrm{CaCO}_{3}$ to $\mathrm{PP}$ improved the tensile properties, due to good dispersion, good coherent, better physical adhesion and strong interactions between them [13]. 
$\mathrm{PP} / \mathrm{CaCO}_{3}$ composite

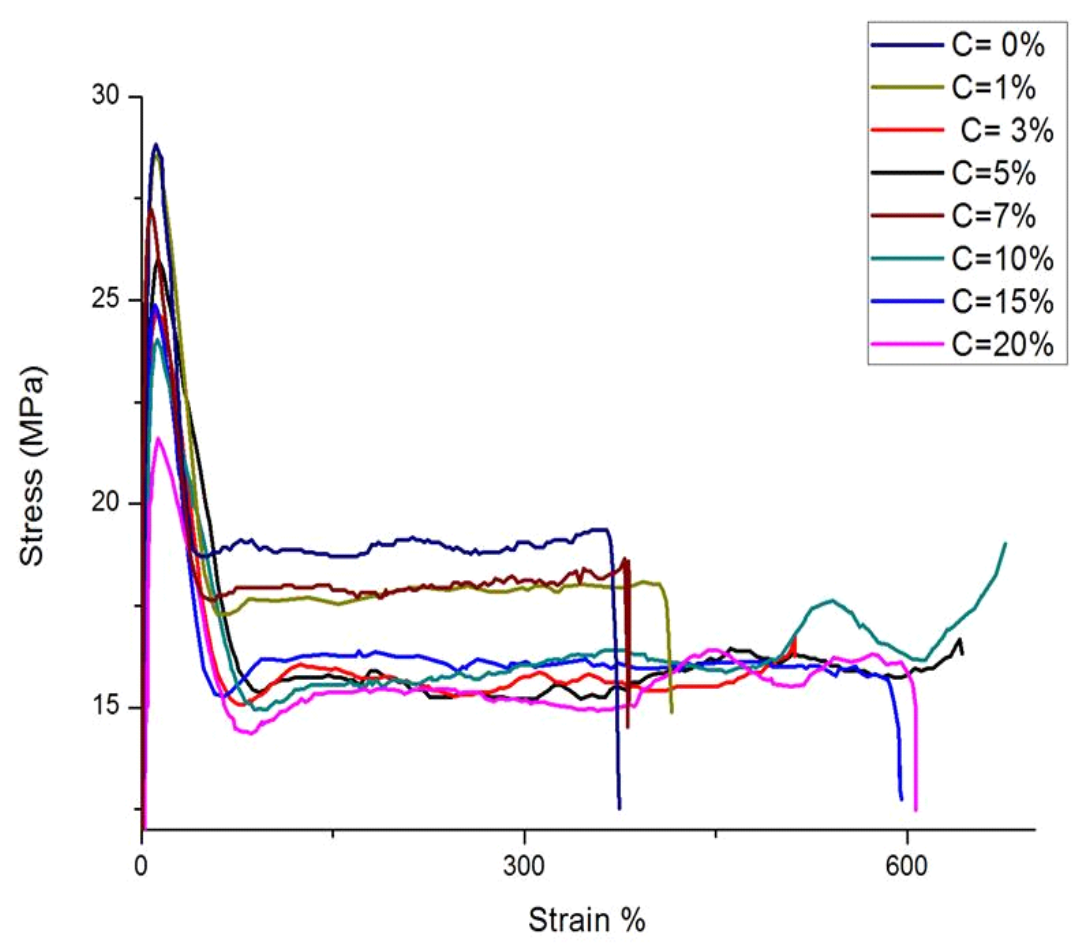

$\mathrm{PP} / \mathrm{CaCO}_{3}$ nanocomposite

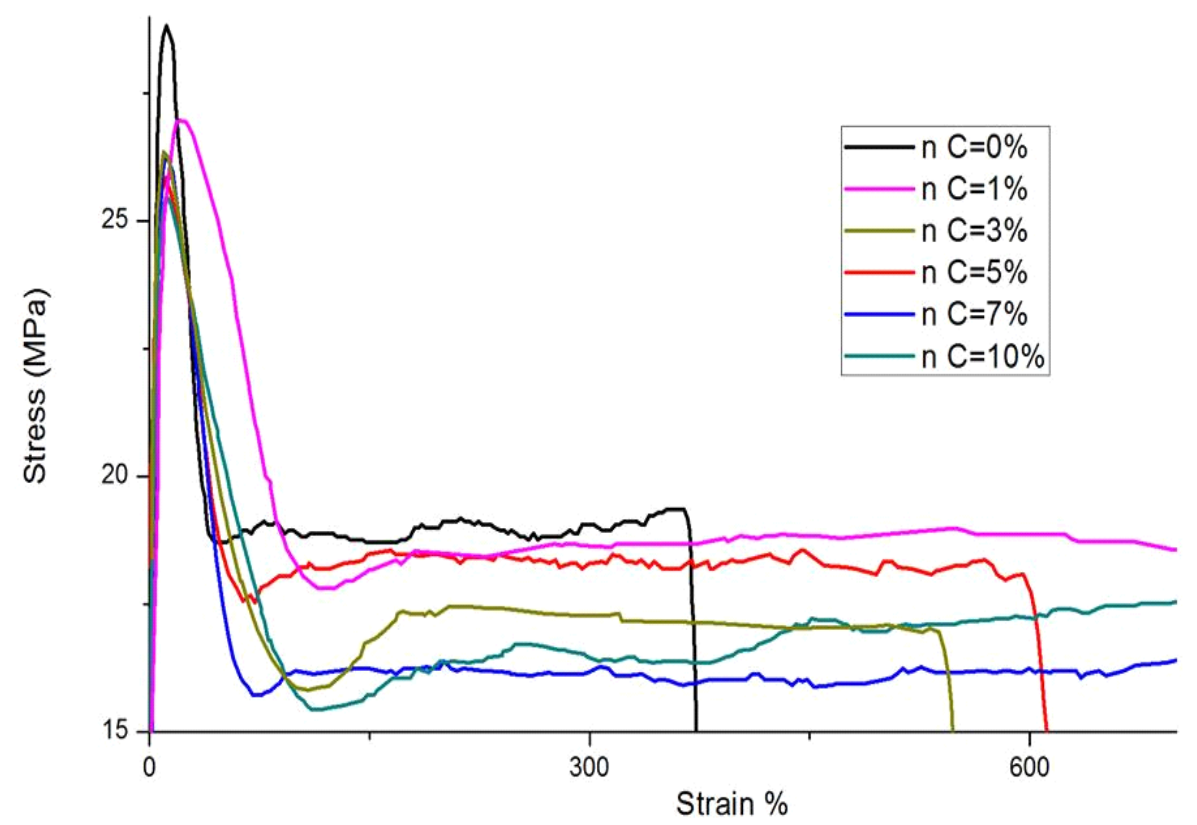

Fig. 5. Stress \& Strain curve for $\mathrm{PP} / \mathrm{CaCO}_{3}$ composite and $\mathrm{PP} / \mathrm{CaCO}_{3}$ nanocomposite. 


\section{Impact Test}

The results represented in Table 1 showed that, for $\mathrm{PP} / \mathrm{CaCO}_{3}$ composites the last sample within $\mathrm{CaCO}_{3}$ contents $20 \%$ was failed, this's because there's no homogenous distribution and agglomeration occurs, the addition of $\mathrm{CaCO}_{3}$ had a negative effect on the impact strength of virgin $\mathrm{PP}$ [14]. But for $\mathrm{PP} / \mathrm{CaCO}_{3}$ nanocomposites, all the samples were passed the test, this means that there's a homogenous distribution of nano $\mathrm{CaCO}_{3}$ inside PP matrix [14].

\section{Hardness}

It was shown that for both $\mathrm{PP} / \mathrm{CaCO}_{3}$ composites and nanocomposites (Fig.6) hardness increase with increasing $\mathrm{CaCO}_{3} \%$ contents, depending upon the distribution of filler into the matrix[15].

\section{Electrical properties}

\section{AC conductivity.}

The frequency dependence of $\delta_{\text {tot }}(\mathrm{w})$ for PP/ $\mathrm{CaCO}_{3}$ composite and nanocomposite (Fig 7), the general behavior describe mild increase of $\delta_{\text {tot }}(\mathrm{w})$ with increasing frequency within relatively low frequency range followed by strong reliance beyond certain frequency relative to the following universal law:

$$
\delta_{\text {tot }}(w)=\delta_{a c}(w)+\delta_{d c}(w) \ldots \ldots . .(3.1)
$$

where,

$\delta_{\mathrm{ac}}(\mathrm{w})$ is the direct current conductivity.

$\delta_{\mathrm{dc}}(\mathrm{w})$ is the frequency dependence conductivity.

\section{DC conductivity}

The dependence of $\left(\delta_{\mathrm{dc}}\right)$ of $\mathrm{PP} / \mathrm{CaCO}_{3}$ composite and nanocomposite on temperature (Fig. 8) can be separated into three regions:-

a- Region (I) from 303333- K, in this region the increasing in $\left(\delta_{\mathrm{dc}}\right)$ could be due to the hydroscopic nature of the samples ease to absorbed water, which provide $\mathrm{H}^{+}$and $\mathrm{OH}^{-}$ ions that cause sharp increase in conductivity.

b- Region (II) from 333393- K, conductivity decreased due to desorption process which reduced $\mathrm{H}^{+}$and $\mathrm{OH}^{-}$ions[16].

c- Region (III) from 393433- K, the conductivity begin to increase due to the thermal activation of charge carriers from the shallow traps $(\Delta \mathbf{E}=0.13-0.48 \mathrm{ev})$.

\section{Dielectric properties}

The variation of dielectric constant $(\varepsilon)$ as function of frequency at room temperature for $\mathrm{PP} / \mathrm{CaCO}_{3}$ composite and nanocomposite (Fig.
9), respectively it was proved that $\varepsilon$ independent upon frequency. This indicates that PP is nonpolar polymer[17].

It was showed that the dielectric constant $(\varepsilon)$ initially increase with increasing $\mathrm{CaCO}_{3}$ contents due to increase in polarizability group with the incorporation of $\mathrm{CaCO}_{3}$. Then, after $10 \mathrm{wt}$. \% of $\mathrm{CaCO}_{3}$ for $\mathrm{PP} / \mathrm{CaCO}_{3}$ composite and 5 wt. \% for $\mathrm{PP} / \mathrm{CaCO}_{3}$ nanocomposite, respectively, the value of the dielectric constant $(\varepsilon)$ decreased due to $\mathrm{CaCO}_{3}$ agglomerations which sufferance the dipoles to be oriented with the oscillatory applied electric field.

\section{Thermal Analysis}

For TGA results:-

It was found that virgin PP showed the lowest thermal stability, based upon $\mathrm{T}_{\mathrm{d}}, 419.03^{\circ} \mathrm{C}$ than $\mathrm{PP} / \mathrm{CaCO}_{3}$ composite and nanocomposite (Fig. 10).

\section{For DSC results}

It is clear that both Tonset and $\mathrm{T}_{\mathrm{m}}$ are nearly unchanged with all $\mathrm{CaCO}_{3}$ contents where $\Delta \mathrm{H}_{\mathrm{m}}$ recording its highest degree at 5 wt. \% for composite and $1 \mathrm{wt}$. \% for nanocomposite recording highest degree of crystallinity fraction, Can be attributed to the increase of composite viscosity during processing which resists the PP structure rearrangement (Fig.11).

The degree of crystallinity fraction (DOC (\%)) can be calculated from the following equation:-

$$
\begin{aligned}
& \text { DOC }(\%)=\frac{\Delta \mathbf{H ~ m}}{\left(\mathbf{1}-W_{f}\right) \cdot \Delta \mathbf{H}^{\circ} \mathrm{m}} \times \mathbf{1 0 0} \\
& \text { Where, } \\
& w_{f} \text { is the weight fraction of PP in the composite } \\
& \mathrm{H}_{\mathrm{m}} \text { is the experimental melting enthalpy } \\
& \mathrm{H}_{\mathrm{m}}^{\circ} \text { is the melting enthalpy for } 100 \% \\
& \text { crystalline PP, }(207.1 \mathrm{~J} / \mathrm{g}) \text {. }
\end{aligned}
$$

\section{Physical properties \\ Density}

Density results for both PP composite and nanocomposite (Fig.12) gradually increases with increasing content of $\mathrm{CaCO} 3$, this is due to higher density of $\mathrm{CaCO} 3$.

\section{Water Absorption Test}

According to hydrophilic nature of $\mathrm{CaCO}_{3}$, Water absorption increase with increasing $\mathrm{CaCO}_{3}$ contents in PP matrix especially in $\mathrm{CaCO}_{3}$ within micron size, due to increasing the exposed surface of water absorption compared with $\mathrm{CaCO}_{3}$ within nano size (Fig.13), enabling to compatible with PP. 

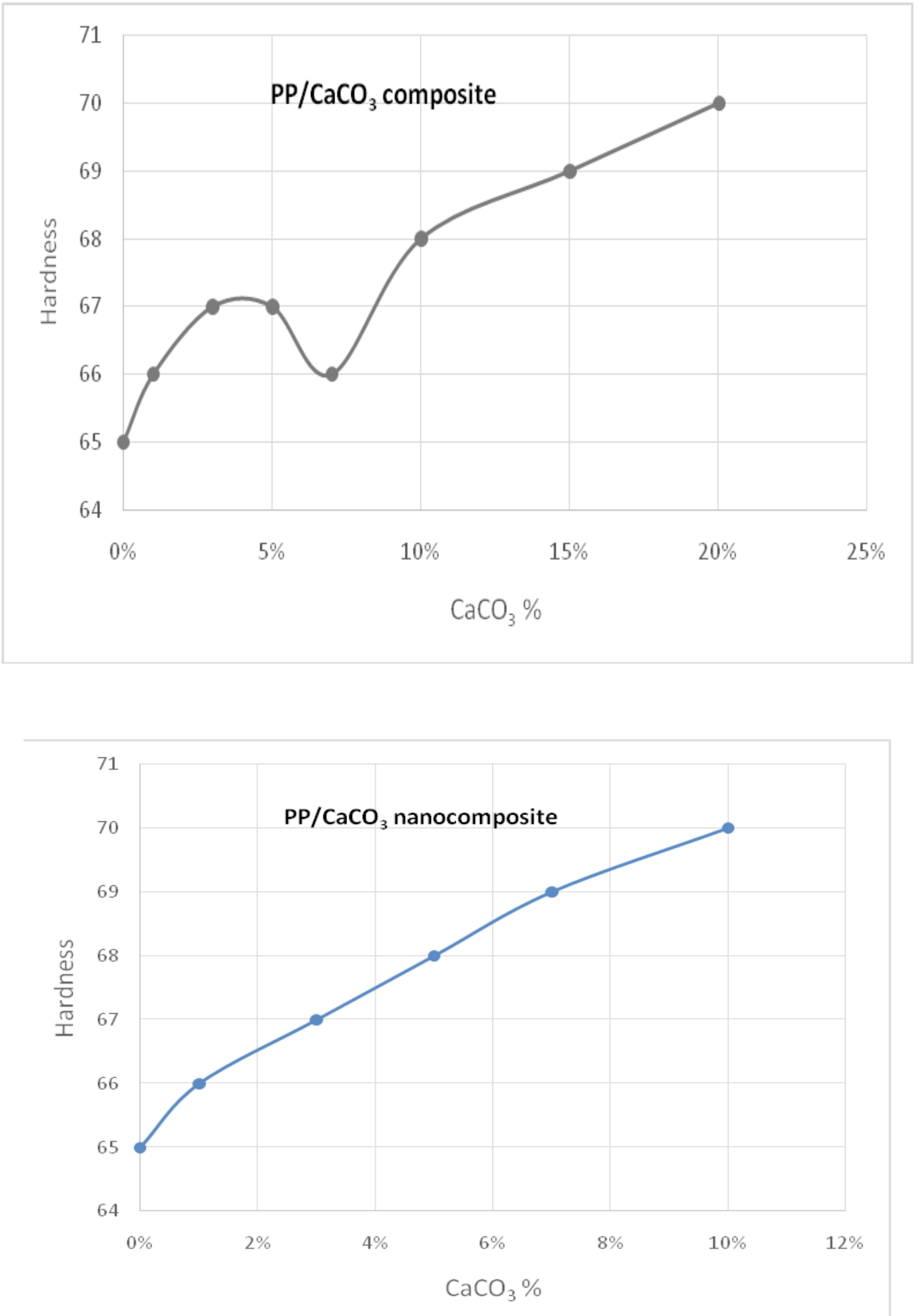

Fig. 6. Hardness(shore D) results for $\left.\mathrm{PP} / \mathrm{CaCO}_{3} \operatorname{com}\right\urcorner$ posites and $\mathrm{PP} / \mathrm{CaCO}_{3}$ nanocom $\neg$ posites.

Egypt. J. Chem. 61, No.5 (2018) 


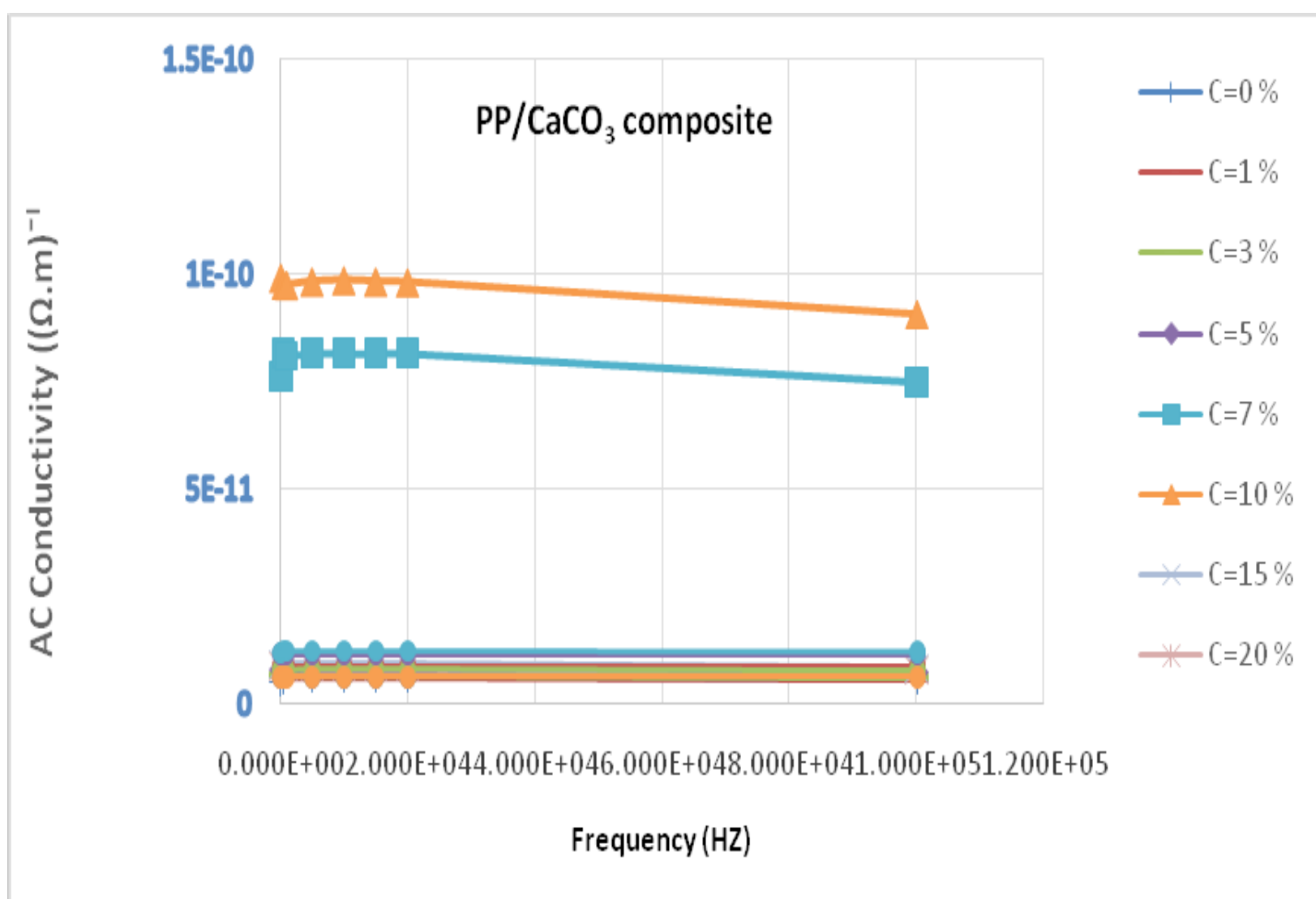

$\mathrm{PP} / \mathrm{CaCO}_{3}$ nanocomposite

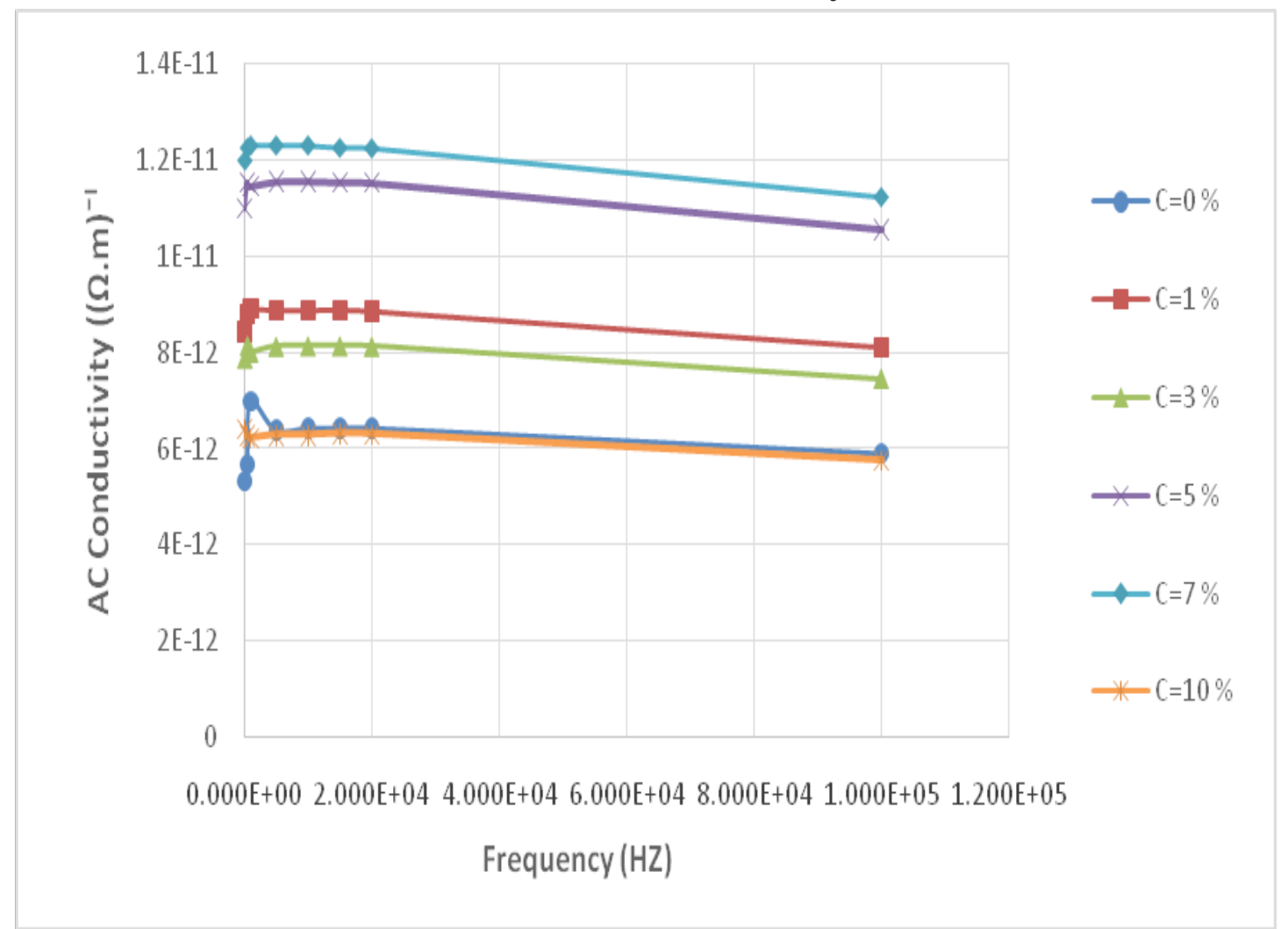

Fig. 7. Frequency dependence of the $\mathrm{AC}$ Conductivity at room temperature for $\mathrm{PP} / \mathrm{CaCO}_{3}$ composite and $\mathrm{PP} /$ $\mathrm{CaCO}_{3}$ nanocomposite. 

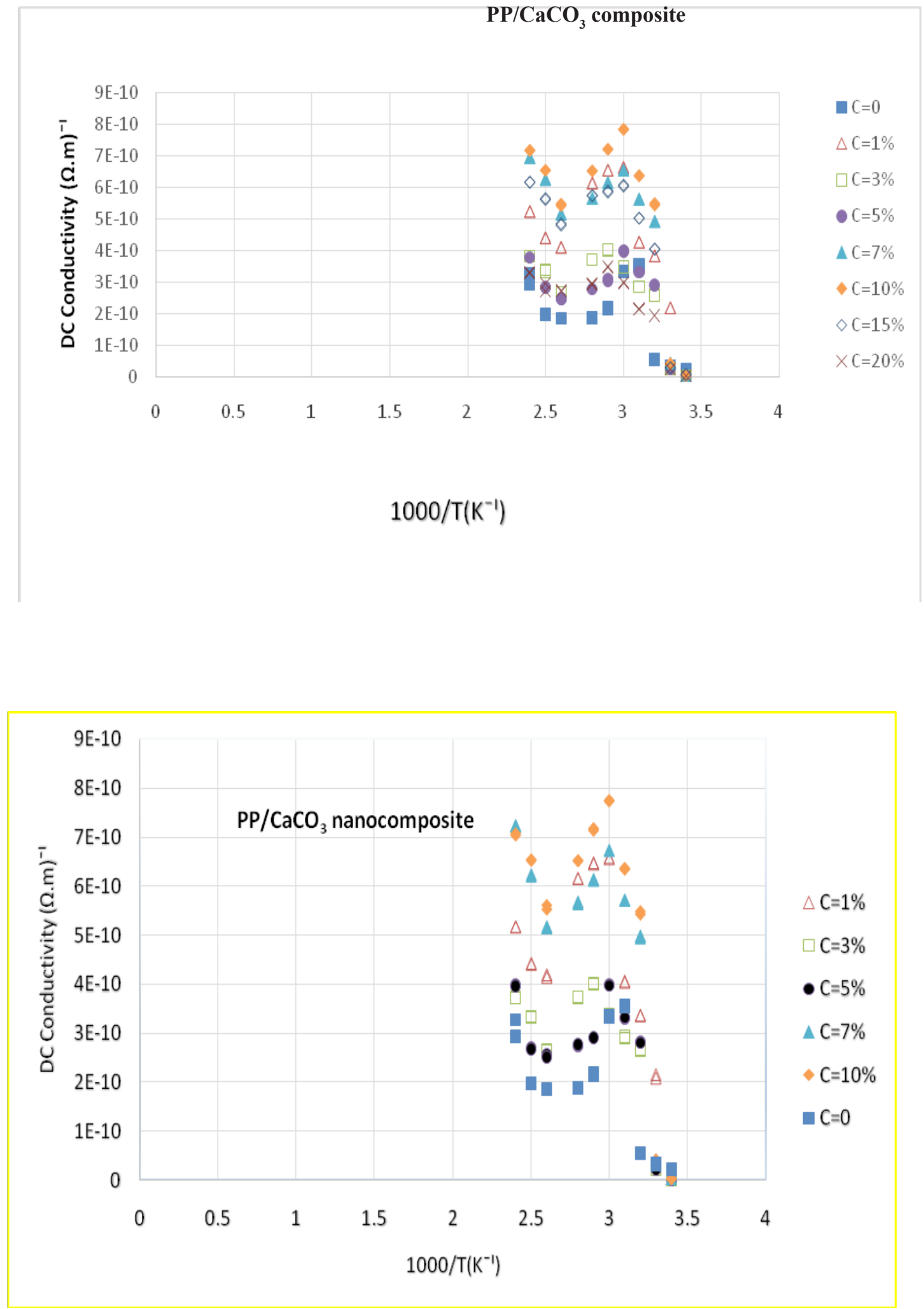

Fig. 8. DC conductivity versus $(1000 / \mathrm{T})$ for $\mathrm{PP} / \mathrm{CaCO}_{3}$ composite and $\mathrm{PP} / \mathrm{CaCO}_{3}$ nanocomposite. 

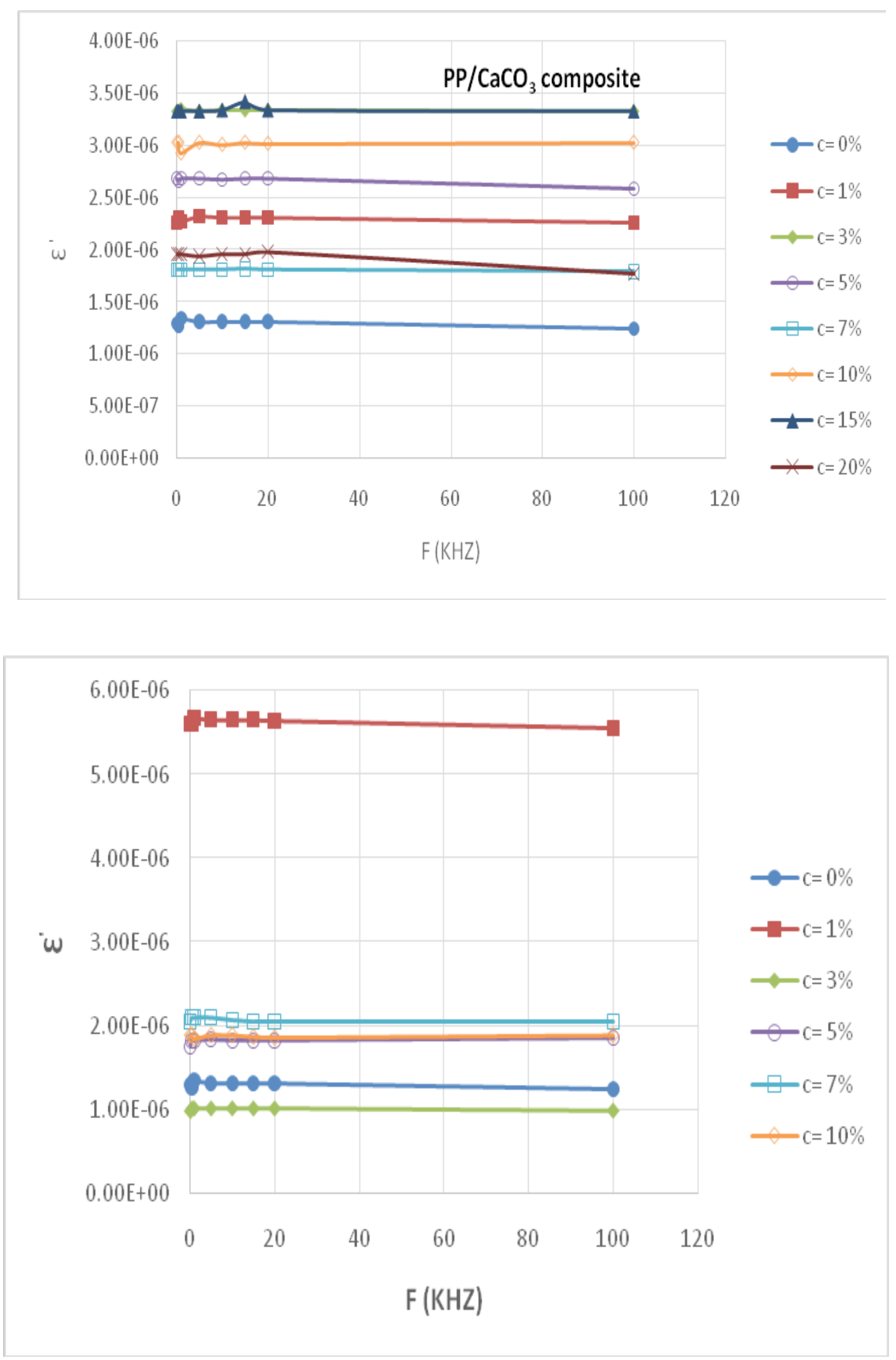

Fig .9. The relation between dielectric constant ( $\left(\right.$,) and frequency at room temperaturefor $\mathrm{PP} / \mathrm{CaCO}_{3}$ composite and $\mathrm{PP} / \mathrm{CaCO}_{3}$ nanocomposite. 

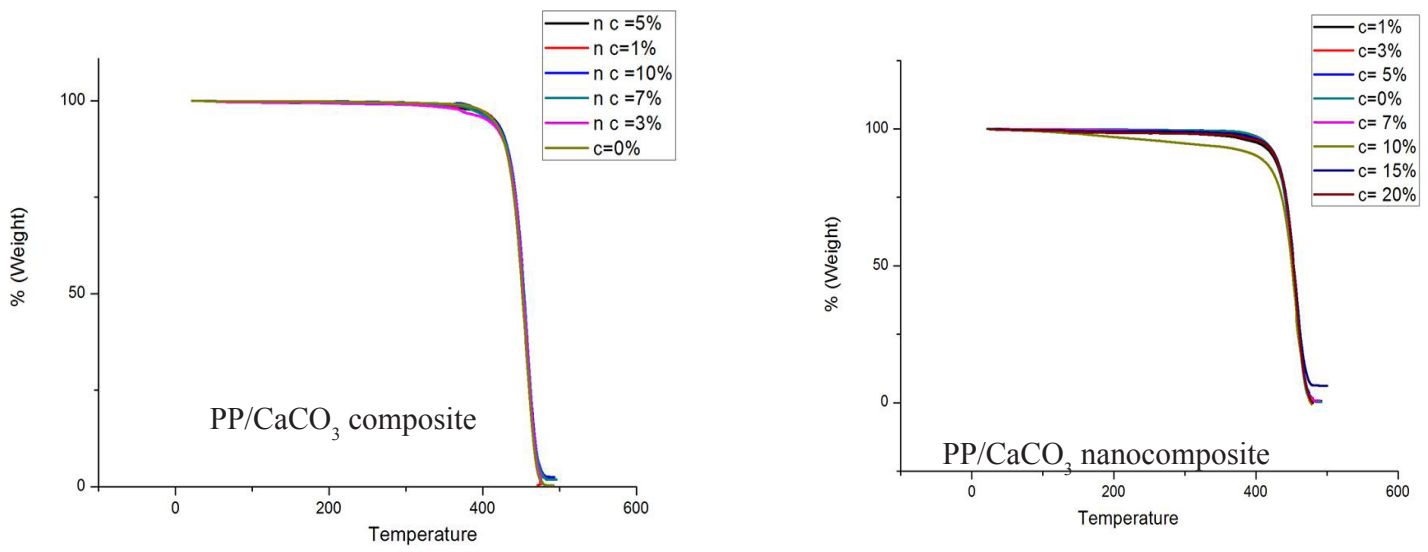

Fig .10. TGA for $\mathrm{PP} / \mathrm{CaCO}_{3}$ composite and $\mathrm{PP} / \mathrm{CaCO}_{3}$ nanocomposite.
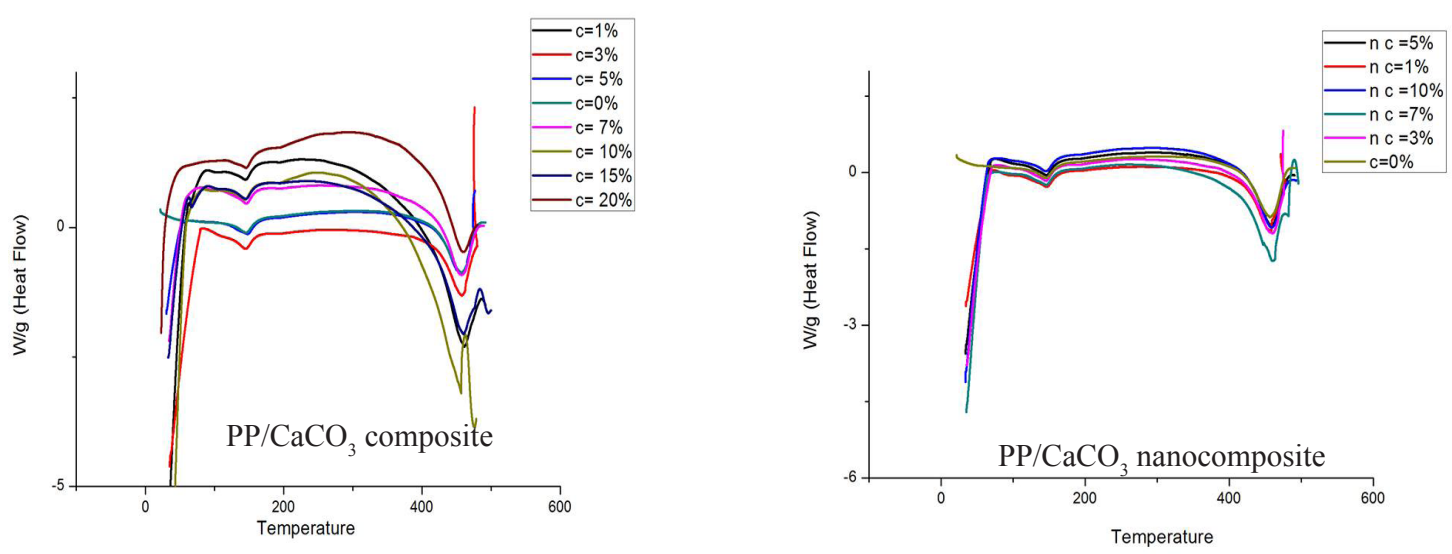

Fig. 11. $\mathrm{DSC}$ for $\mathrm{PP} / \mathrm{CaCO}_{3}$ composite and $\mathrm{PP} / \mathrm{CaCO}_{3}$ nanocomposite.
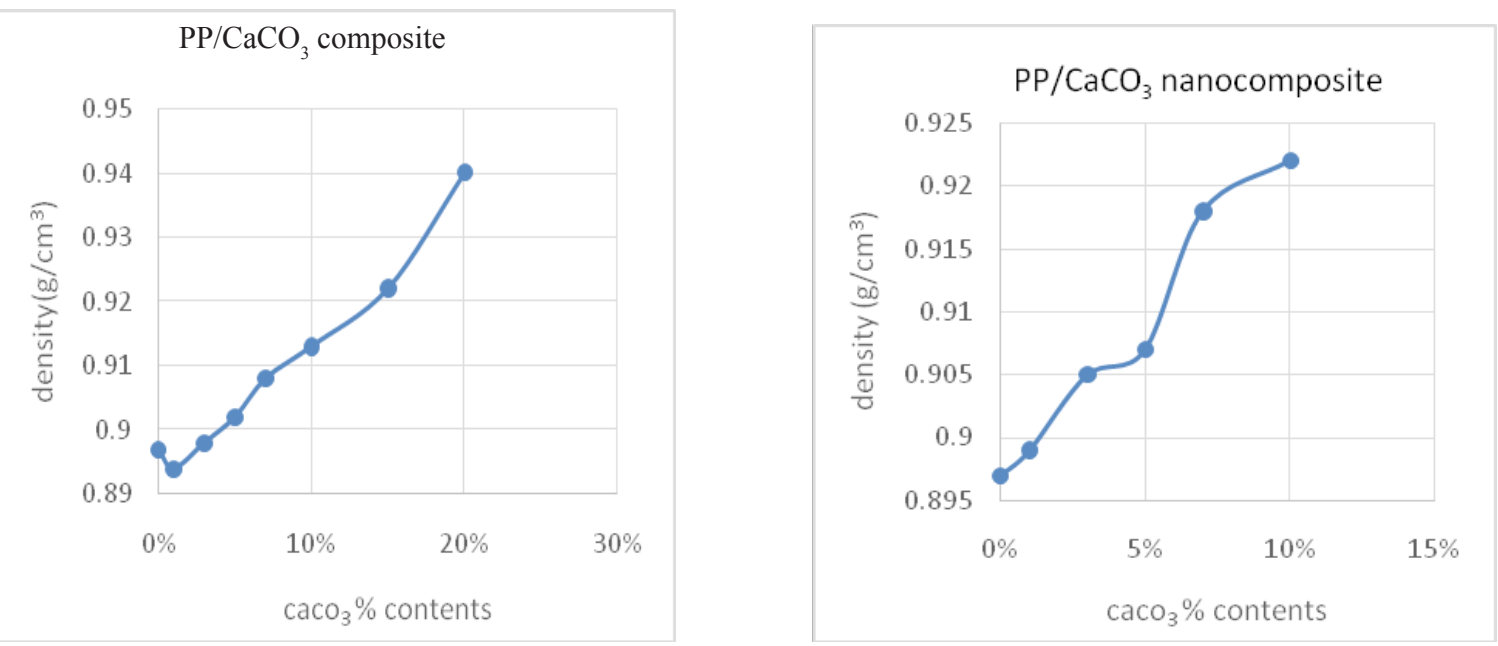

Fig. 12. Density for $\mathrm{PP} / \mathrm{CaCO}_{3}$ composite and $\mathrm{PP} / \mathrm{CaCO}_{3}$ nanocomposite. 

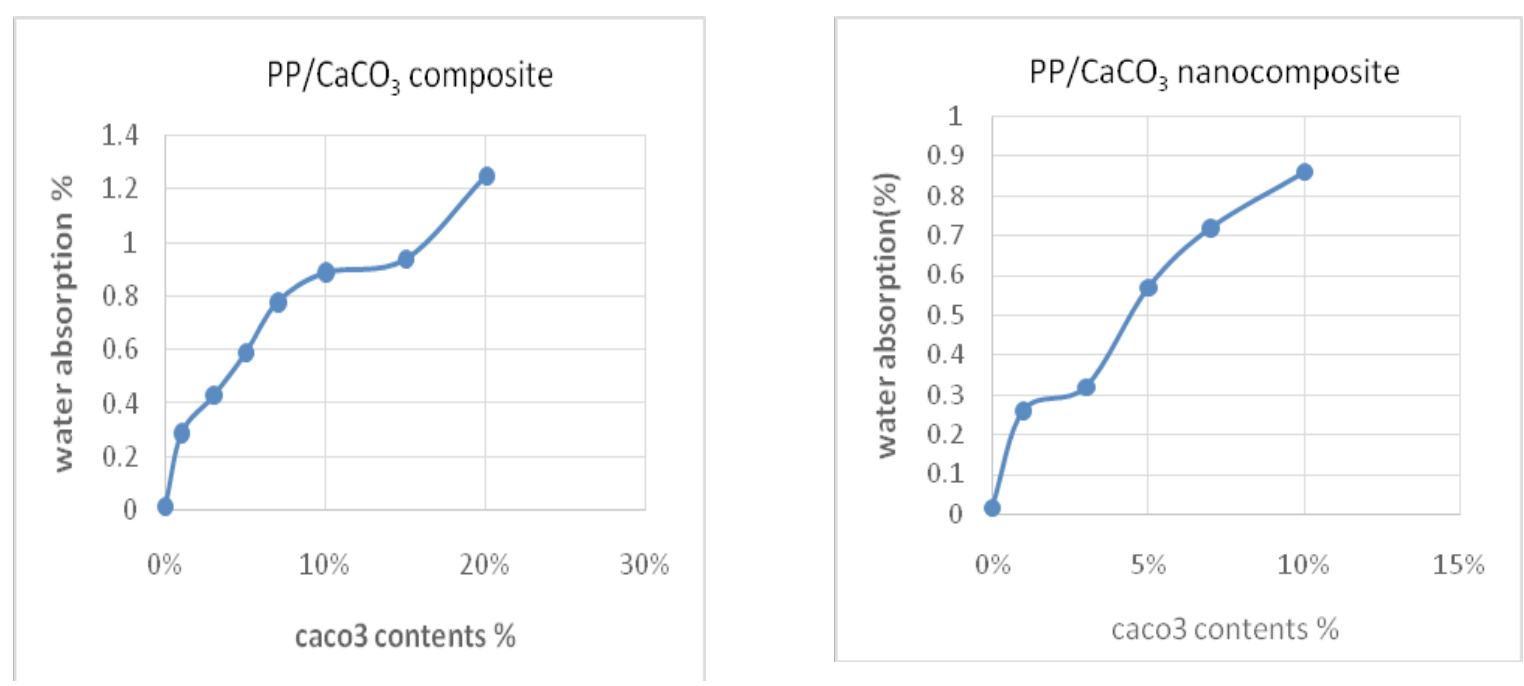

Fig. 13. Water absorption for $\mathrm{PP} / \mathrm{CaCO}_{3}$ composite and $\mathrm{PP} / \mathrm{CaCO}_{3}$ nanocomposite.

\section{Flow Characteristics}

Melt Flow Index (MFI) Test

the results shown in Fig.14 that Melt Flow Rate increases with increasing $\mathrm{CaCO}_{3}$ contents, due to decreasing flow resistance then decrease:-

1- For the $\mathrm{PP} / \mathrm{CaCO}_{3}$ composites, Melt Flow rate (MFR) increases till $\mathrm{CaCO}_{3}$ contents $15 \%$ then decreases.

2- For the $\mathrm{PP} / \mathrm{CaCO}_{3}$ nanocomposites, Melt Flow rate (MFR) increase till $\mathrm{CaCO}_{3}$ contents $7 \%$ then decrease.

Decreasing in Melt Flow rate after increasing due to torque increasing caused by adhesion take place between the material and (external surface of screw and internal surface of barrel).

Heat reversion

All results in Fig.15 showed that heat reversion affected with increasing $\mathrm{CaCO}_{3}$ contents, Longitudinal contraction decreases with increasing $\mathrm{CaCO}_{3}$ wt. \%, which Interfaces in $\mathrm{PP}$ matrix.

Vicat Softening Temperature and Heat Deflection Temperature

In accordance with hardness results, it was found that both VST in Fig. 16 and HDT in Fig. 17 increase with increasing $\mathrm{CaCO}_{3}$ contents for both $\mathrm{PP} / \mathrm{CaCO}_{3}$ composite and nanocomposite.

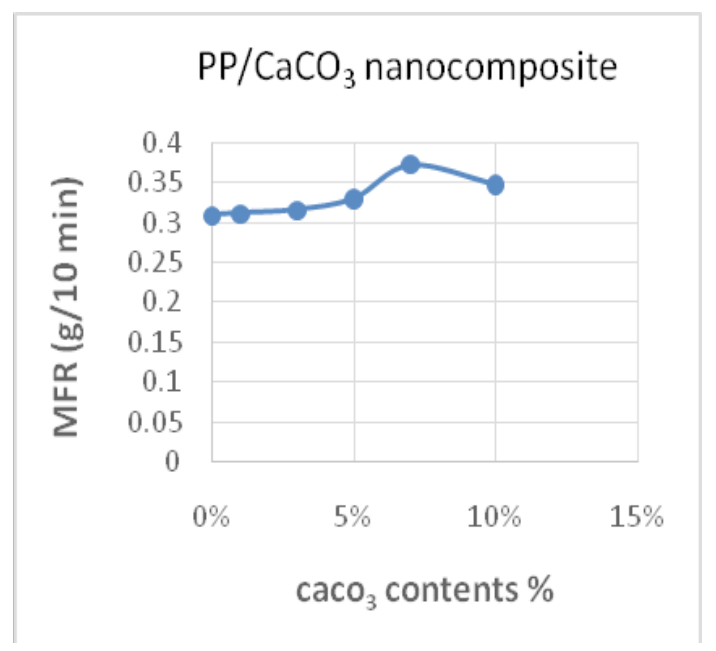

Fig. 14. $\mathrm{MFR}$ for $\mathrm{PP} / \mathrm{CaCO}_{3}$ composite and $\mathrm{PP} / \mathrm{CaCO}_{3}$ nanocomposite at $230{ }^{\circ} \mathrm{C} / 2.16 \mathrm{~kg}$. 

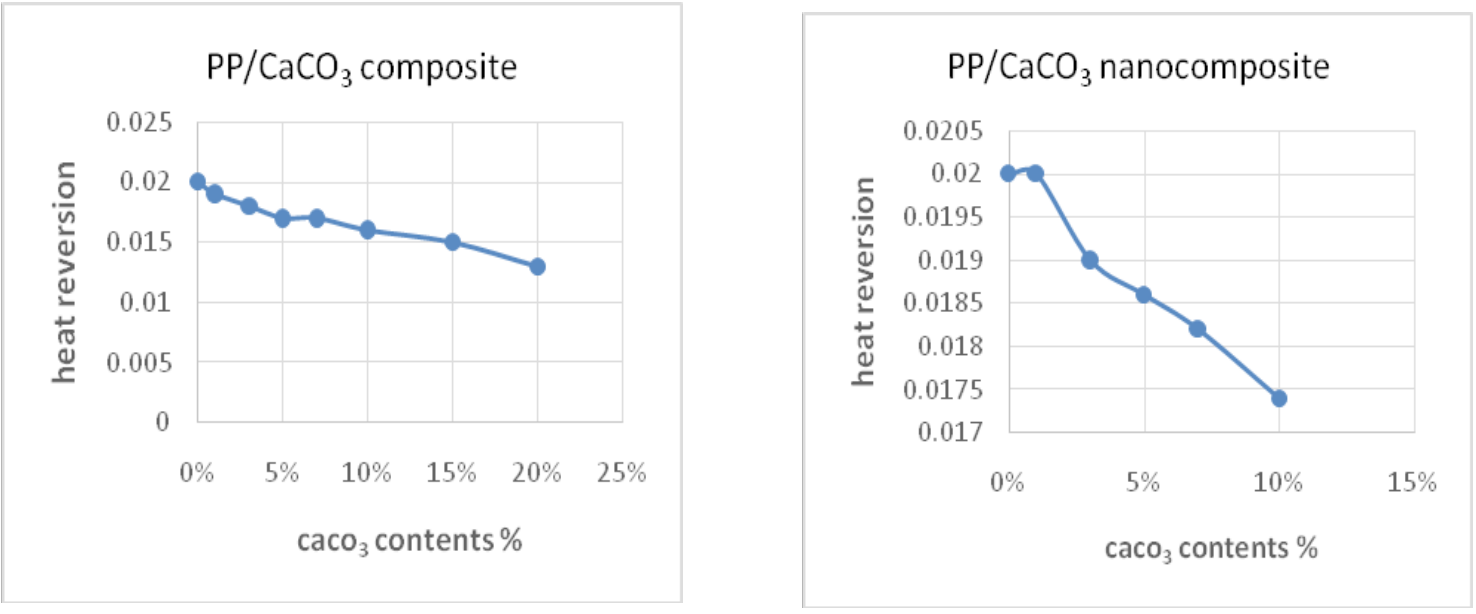

Fig. 15. Heat reversion for $\mathrm{PP} / \mathrm{CaCO}_{3}$ composite and $\mathrm{PP} / \mathrm{CaCO}_{3}$ nanocomposite.
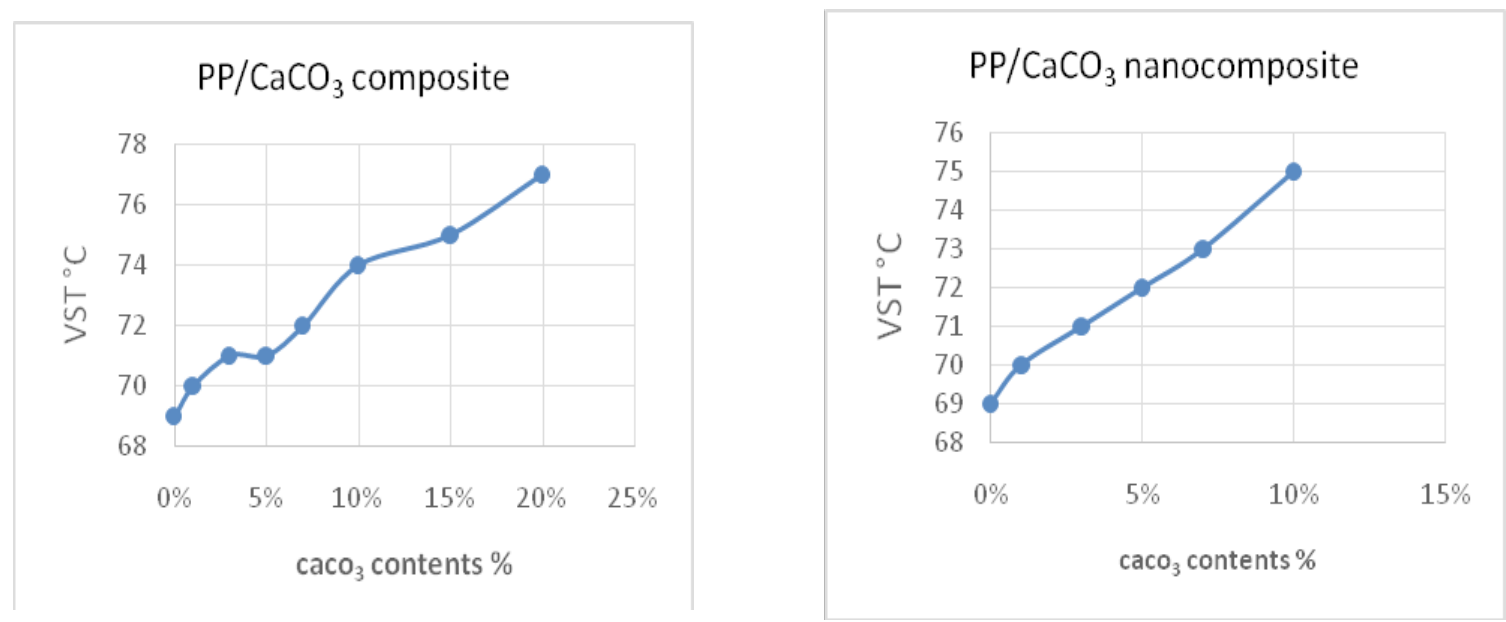

Fig . 16. VST for $\mathrm{PP} / \mathrm{CaCO}_{3}$ composite and $\mathrm{PP} / \mathrm{CaCO}_{3}$ nanocomposite.
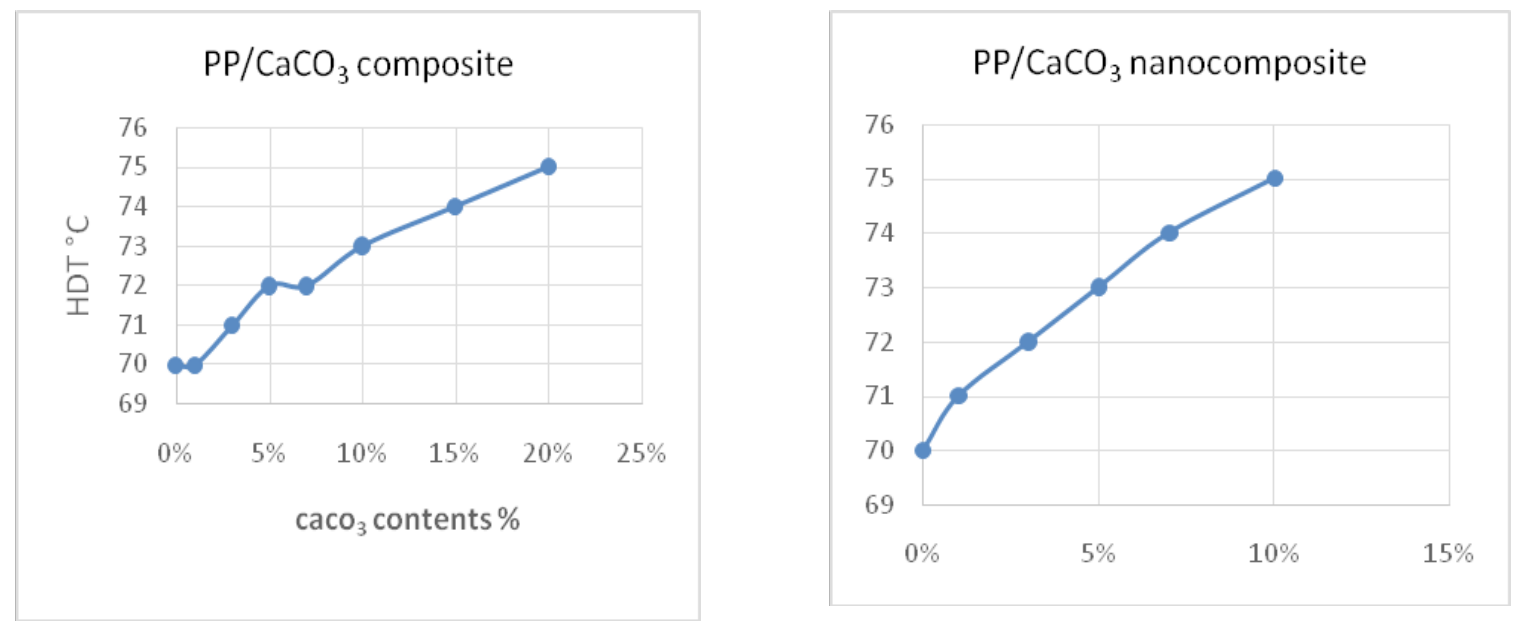

Fig. 17. $\mathrm{HDT}$ for $\mathrm{PP} / \mathrm{CaCO}_{3}$ composite and $\mathrm{PP} / \mathrm{CaCO}_{3}$ nanocomposite. 


\section{Conclusion}

FTIR results showed that there is no chemical change in the prepared PP composite. XRD results indicated that there is no effect on the crystallinity of PP by adding $\mathrm{CaCO}_{3}$. TEM results indicated good dispersion of $\mathrm{CaCO}_{3}$ especially nano size till certain value then, agglomeration occurs. Mechanical properties indicated that strain at break and elongation at break improved and reach its maximum value at $15 \mathrm{wt} . \%$ micro $\mathrm{CaCO}_{3}$ and 7 wt. \% nano $\mathrm{CaCO}_{3}$. Impact Test showed failing of micro $\mathrm{CaCO}_{3}$ composite with 20 wt. \%. Electrical properties, mild increase of $\delta_{\text {tot }}(\mathrm{w})$ with increasing frequency within relatively low frequency range followed by strong reseliance beyond certain frequency. Dielectric constant remains constant with increasing frequency for each sample, but increase till the concentration of $10 \mathrm{wt}$ \% micro $\mathrm{CaCO}_{3}$ and 5 wt. $\%$ nano $\mathrm{CaCO}_{3}$ then decreases. Thermal Analysis, slight improvement in thermal stability of PP by adding $\mathrm{CaCO}_{3}$ but, both Tonset and $T_{m}$ are nearly unchanged. MFR improved and reach its maximum value at $15 \mathrm{wt}$. \% micro $\mathrm{CaCO}_{3}$ and 7 wt. \% nano $\mathrm{CaCO}_{3}$ then decrease. Longitudinal contraction decrease with increasing $\mathrm{CaCO}_{3}$ wt. \%. Finally, it was detected that density, Water absorption, Hardness, VST and HDT increases with increasing $\mathrm{CaCO}_{3}$ wt. \%.

\section{References}

1. Toro P., Quijad R., Peralta R., Yazdani-Pedram M., Influence of grafted polypropylene on the mechanical properties of mineral-filled polypropylene composites. J Appl Polym Sci.; 103(4), 2343-50. (2007).

2. Zhidan L., et al. Crystallization and melting behavior of polypropylene in b-PP/polyamide 6 blends containing PP-g-MA. J Ind Eng Chem.; 19(2), 692-7 (2013).

3. Griffiths P.R., DeHaseth J. A., Fourier Transfonm Infrared Spectroscopy, John Wiley and Sons Inc., New York (1986).

4. Czichos, Horst HYPERLINK "https://books. google.com/books?id=81ANaR-Pqi4C"Springer Handbook of Materials Measurement Methods. Berlin: Springer. pp. 303-304. HYPERLINK "https://en.wikipedia.org/wiki/International_ Standard_Book_Number" lo "International Standard Book Number"ISBN HYPERLINK "https://en.wikipedia.org/wiki/Special:BookSo urces/978-3-540-20785-6" lo "Special:BookSo urces/978-3-540-20785-6"978-3-540-20785-6. (2006).

5. DIN EN ISO 527-1, Plastics - Determination of tensile properties - Part 1:General principles (2012).

6. ASTM D 570,"Standard Test Method for water absorption (1995).

7. HYPERLINK "https://www.iso.org/obp/ui/" \l "iso:std:iso:1133:-2:en"ISO 1133, Plastics Determination of the melt mass-flow rate (MFR) and melt volume-rate (MVR) of thermoplastics, part 1:(2011)(E).

8. ISO 2505:, Thermoplastics pipes -- Longitudinal reversion -- Test method and parameters (2005)

9. ASTM D 648-6 Test method for deflection temperature (2007)

10. Yuan Y., Chen B. and Zhang X. Study on the formation of $\beta$-crystal during the crystallization process of polypropylene reactor granule. Polymer.; 47(15), 5480-5483 (2006).

11. Hou W.M., Liu G., Zou J.J., Gao X., Li Y., Li L. et al. The influence of crystal structures of nucleating agents on the crystallization behaviors of isotactic polypropylene. Colloid and Polymer Science.; 285(1), 11-17 (2006).

12. Yasser Zare "Study of nanoparticles aggregation/ agglomeration in polymer particulate nanocomposites by mechanical properties. composites Part Applied Science and Manufacturing May (2016)

13.Cai H. Z., Yang K. Y., Yi W. M., Effect of Calcium Carbonate on Preparation and Mechanical Properties of Wood/Platic Composite. Int. J. Agric.\& Biol. Eng. 10 (1), 184-190 (2017).

14. ASTM D 3029 or D 256-93a Impact Strength.

15. ASTM D 2240 Hardness measurements .

16. Blythe T., Bloor D., "Electrical Properties of Polymers" 2th Ed., Cambridge University Press (2005)

17. Myers H. P., "Introductory Solid State Physics," Taylor \& Francis, London (1990)

(Received 22/5/2018; accepted 26/6/2018)

Egypt. J. Chem. 61, No.5 (2018) 


\title{
دراسة بعض خواص المتر اكبات النانويه للبولى بروبلين
}

\author{
أبو الفتوح عبدالمنعم عبدالحكيم', عبدالله عبدالمنعم الصاوى", أحمد مجدى حسين مطاوع", علاء ابراهيم أحمد عيد؛؛

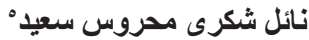

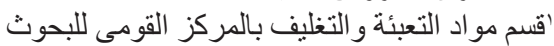

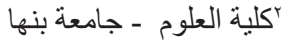

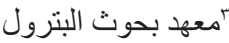 \\ كركز بحوث و تطوير الفلزات

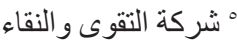

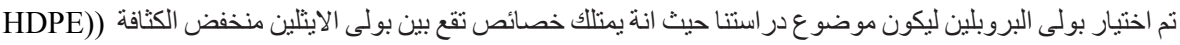

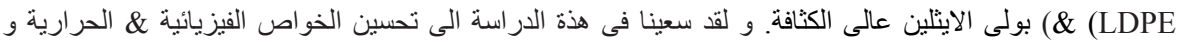

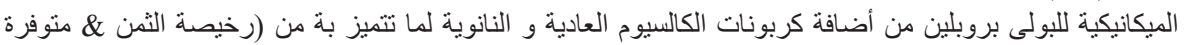

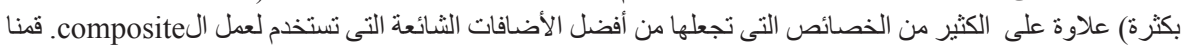

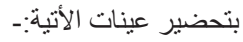

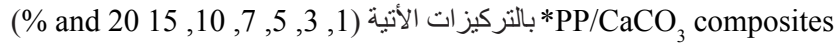
PP/CaCO 3 nanocomposites * الفتيلة عند درجة حرارة تتز اوح ما بين 200-210 درجة سيليزية و عدد لفات 70 لفة فى الدقيقة و زمن خلط 10 دقائق

لضمان تجانس الخامة.

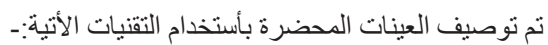
(a) در اسة طيف الأشعة تحت الحمر اء (FT-IR Transmission Spectra) فى المدى من (4000- 400) سم-1 لكلا من PP/ $\mathrm{CaCO}_{3}$ composites and nanocomposite. حيث أوضحت النتائج ظهور بعض القمم تثير الى امتصاص Ce=O, C=C and C-H مض الروابط منل

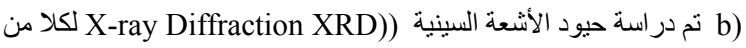
PP/ $\mathrm{CaCO}_{3}$ composites and nanocomposite

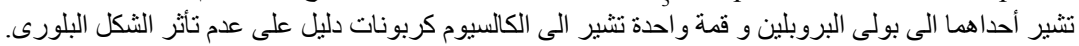

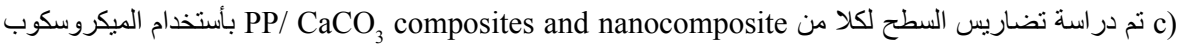
الالكترونى النافذ (TEM) حيث أظهرت النتائج أن بزيادة تركيز الكالسيوم كربونات يؤدى الى ظهور تجمعات غير متجانسة

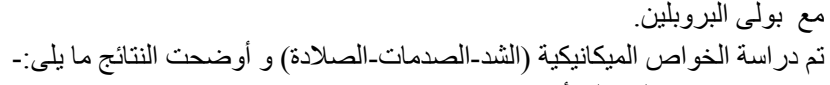

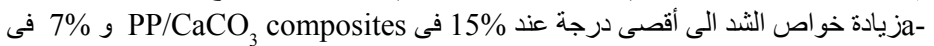
PP/ CaCO nanocomposites

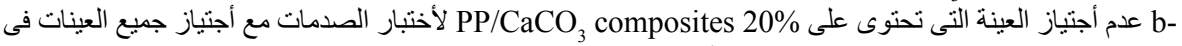

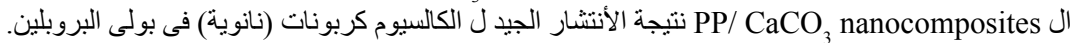

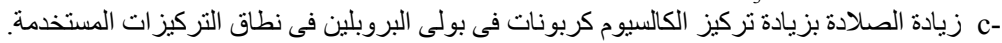

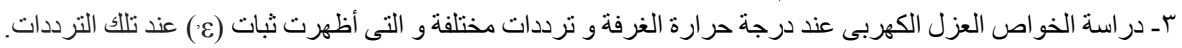

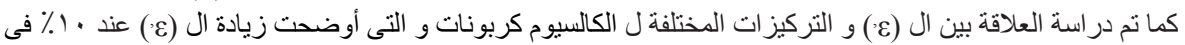

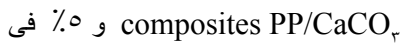

nanocomposites PP/ $\mathrm{CaCO}_{r}$

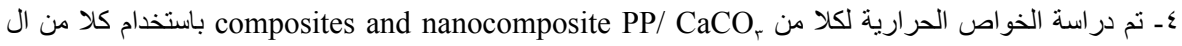
حيث أظهرت النتائج عدم وجود تغيير فى درجة حرارة الأنصهار للبولى بروبلين مع زيادة تركيز

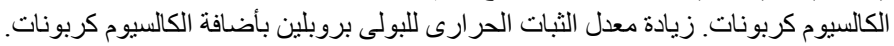

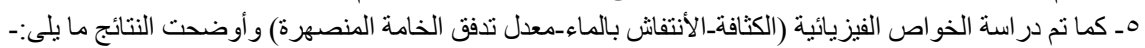

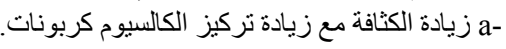

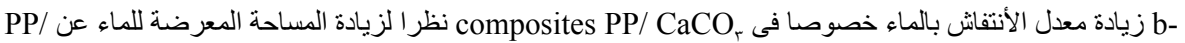
nanocomposite $\mathrm{CaCO}_{r}$

$$
\text { (MFR) زيادة تدفق الخامة المنصهرة c- }
$$

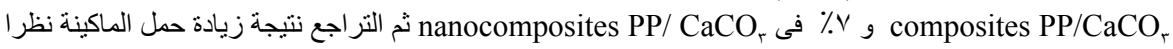

لحدوث التصاق بين الخامة المستخدمة مع كلا من (سطح الأسطو انة الداخلى و سطح الفتيل الخارجى).

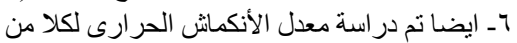
composites and nanocomposite PP/ $\mathrm{CaCO}_{r}$

$$
\begin{aligned}
& \text { الكالسيوم كربونات. } \\
& \text { Vـ و أخير ا تم در اسة كلا من (VST) و (HDT) و الذين يزيدان مع زيادة تركيز الكالسيوم كربونات. }
\end{aligned}
$$

Egypt. J. Chem. 61, No.5 (2018) 